\title{
Cervical esophageal rupture after blunt trauma resulting from a car accident
}

\author{
Piotr Misiak, Sławomir Jabłoński, Artur Terlecki \\ University Clinical Hospital No. 2 (Central Veterans Hospital), Lodz, Poland \\ Kardiochirurgia i Torakochirurgia Polska 2016; 13 (3): 262-264
}

\begin{abstract}
Traumatic perforation of the cervical esophagus due to blunt trauma is a very rare condition which continues to be associated with significant mortality rates. The symptoms and signs of this injury are often masked by or ascribed to more common blunt thoracic injuries. This paper presents a case of cervical esophageal perforation secondary to blunt trauma resulting from a car accident. The injury was diagnosed early by computed tomography examination, and the patient underwent prompt and successful surgical repair performed to prevent the development of descending mediastinitis.
\end{abstract}

Key words: blunt chest trauma, esophageal perforation.

\section{Introduction}

Esophageal perforation may result from iatrogenic, penetrating, or blunt trauma. Most cases are secondary to endoscopic examination and usually occur in the cervical part; nevertheless, esophageal injuries due to blunt trauma are very rare and account for less than $10 \%$ of all esophageal injuries. Perforation due to blunt trauma is extremely rare, with an incidence of less than 1\% (0.001\%). In 82\% of cases, esophageal perforation secondary to blunt chest trauma occurs above the level of the carina [1].

\section{Case report}

The 24-year-old male patient was a driver who participated in a car accident; he was admitted to the Emergency Department of University Clinical Hospital No. 2 in Lodz with multiple injuries. The car driven by the patient rolled over, and the victim fell through the windshield; according to the report of the ambulance team leader, the victim was not wearing a seat belt. On admission, the patient was stable and in deep pharmacological analgesia.

A full-body computed tomography (CT) scan was performed. The examination revealed a number of post-traumatic lesions including subdural hematomas in the area of

\section{Streszczenie}

Uszkodzenie szyjnego odcinka przełyku w wyniku urazu tępego zdarza się rzadko i w dalszym ciągu wiąże się z dużym odsetkiem zgonów. Objawy kliniczne i wyniki badań obrazowych są często maskowane lub przypisywane innym, częściej spotykanym zmianom, które występują po tępych urazach klatki piersiowej. W poniższym doniesieniu pragniemy zaprezentować przypadek perforacji przełyku w wyniku tępego urazu klatki piersiowej u pacjenta będącego uczestnikiem wypadku komunikacyjnego. Obrażenie to zostało szybko zdiagnozowane $w$ badaniu tomografii komputerowej oraz skutecznie, wcześnie zaopatrzone chirurgicznie w celu zapobieżenia rozwojowi zstępującego zapalenia śródpiersia.

Słowa kluczowe: tępe obrażenia klatki piersiowej, perforacja przełyku.

the temporal lobes (thickness: approx. $11 \mathrm{~mm}$ ). The patient had multiple fractures in the craniofacial area: a frontal bone fracture, a fracture of the left zygomatic process of the frontal bone, fractures of all the walls of the left eye socket, fractures of the anterior and posterior walls of both maxillary sinuses, a nasal bone fracture, and hematomas in the paranasal sinuses. Chest CT revealed an esophageal rupture at the height of the clavicle, which caused an extensive subcutaneous emphysema (Fig. 1); the examination also revealed hemorrhagic contusions within the lower lobes of both lungs. There were no abnormalities in the ab-

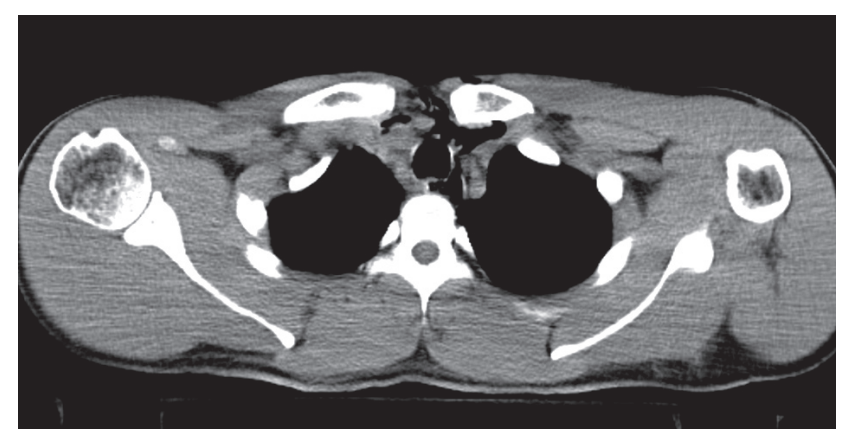

Fig. 1. Computed tomography: esophageal rupture

Address for correspondence: Piotr Misiak MD, PhD, University Clinical Hospital No. 2 (Central Veterans Hospital), 113 Żeromskiego St, 90-549 Lodz, Poland, phone: +48 510115 108, e-mail: pitmis@interia.pl

Received: 17.12 .2015 , accepted: 6.06 .2016$. 
dominal cavity. Examination of the pelvic region revealed a fracture of the right upper part of the right femur.

After the patient's vital signs were stabilized, the trauma team, having discussed the wide extent of the injuries, decided that the priority was to repair the ruptured esophagus.

Taking into consideration the left-sided position of the esophagus, an incision was performed on the left side of the neck from the height of the left sternoclavicular joint to the level of the mandibular angle. After the esophagus was exposed, the perforation site was located; it turned out to be several centimeters above the location indicated by the CT scan. The perforation site was stapled using single-layer interrupted sutures (Fig. 2). A suction drain was placed near the suture line.

After the surgical procedure, the patient was transferred to the intensive care unit (ICU) for further treatment. Additional maxillofacial and orthopedic procedures were performed in the subsequent days. The perforation site healed properly, and the protective drain was removed on the third day after the initial surgery. The patient remained in the ICU for 3 weeks; after this period, he was transferred to the neurological department for further conservative treatment.

\section{Discussion}

Esophageal perforation is a serious injury to the gastrointestinal tract. The associated mortality rates range between $5 \%$ and $40 \%[2,3]$ and are worsened by delayed diagnosis. If the treatment is started after 24 hours from the injury, the mortality rate can increase to $50 \%$ [2].

The mechanism of esophageal perforation in blunt trauma is unclear. The condition can be caused by an increase in intraluminal pressure against a closed glottis, resulting in a tear at the weakest point of the wall, usually in the distal part situated in the left pleural cavity. Other postulated causes include disruption of the esophageal blood supply, resulting in local ischemia and delayed perforation, and a blast effect caused by coexisting tracheal injury. Direct injury may also result from hyperextension-flexion of the neck with concomitant spine fractures or compression between the sternum and thoracic spine, as observed in high-speed road traffic accidents.

Patients with esophageal perforation may present with different clinical symptoms such as dysphagia, odynophagia, chest pain, dyspnea, cervical edema, subcutaneous emphysema, or fever. Mediastinal emphysema can be identified by a "crunching" sound heard on auscultation, known as Hamman's sign. Mackler's triad (which comprises chest pain, vomiting and subcutaneous emphysema) is only found in a minority of the patients. According to the available literature, the most common presenting symptoms of esophageal perforation are pain (71\%), fever (51\%), dyspnea (24\%), and crepitus (24\%) [4].

Our patient was deeply unconscious on admission, and the major clinical symptom was subcutaneous emphysema.

Esophageal rupture resulting from blunt trauma is very often undiagnosed. It is part of the so-called "overlooked

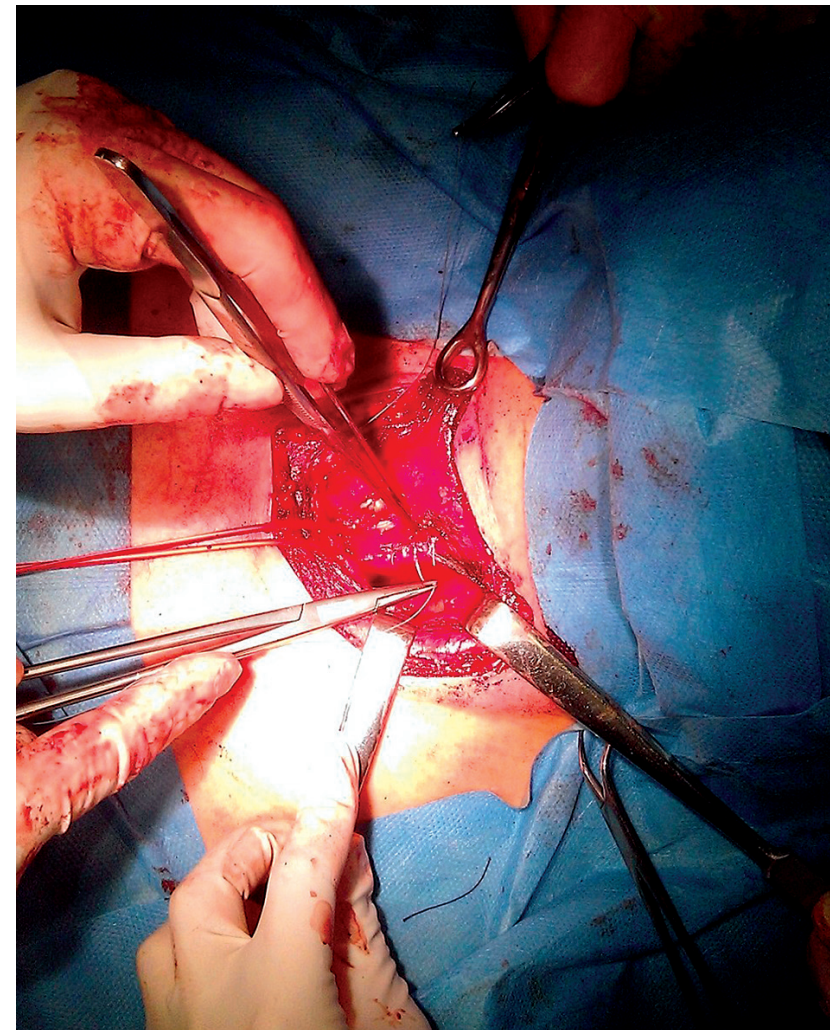

Fig. 2. Suture of the esophageal perforation

six" along with traumatic rupture of the aorta, bronchial tree injury, blunt heart injury, rupture of the diaphragm, and lung contusion [5].

Early diagnosis of the perforation and infection control are key in the management of the condition. Usually, the patient undergoes a CT examination, which is the preferred examination in any patient with multiple organ injuries. In the case of pneumothorax coexisting with hemothorax, chest drainage is performed. Unusual fluid drainage should prompt further diagnostic procedures to exclude esophageal perforation. In our case, CT revealed the perforation site immediately, but a secondary examination in the form of water-soluble contrast esophagography is often required. It is important to remember that this pattern of imaging may have a false negative rate of up to $36 \%$; therefore, if the results are negative, but esophageal perforation continues to be suspected, barium contrast esophagography or esophagoscopy is performed $[4,6]$.

The decision whether to perform primary repair or diversion is time-dependent. When the perforation is identified within 24 hours after the injury, the best approach is to perform primary repair with or without a pleural or muscle flap. The mortality rate in these cases is approximately $12 \%$. Drainage, exclusion, and diversion are the options for unstable patients when the time elapsed from the injury exceeds 24 hours. The associated mortality rate is higher and ranges from $20 \%$ to $36 \%$ [4].

So far, there have been few publications about conservative treatment of esophageal rupture. The strict criteria for non-operative management established by Cameron 
and Altorjay include drainage of the cavity back to the esophagus, minimal signs of clinical sepsis, non-neoplastic etiology, and cervical or thoracic location [6, 7]. However, even if these criteria are met, up to $20 \%$ of patients treated conservatively will require surgical intervention [7].

In our case, the primary repair of the esophageal perforation was performed within 2 hours after diagnosis, before all other surgical and orthopedic procedures.

Recently, it has been reported that mortality due to esophageal perforations has diminished independently of the time of presentation. Morbidity remains very high (particularly when the treatment is delayed), requiring multiple procedures and prolonged hospitalization in the ICU and surgical wards.

According to international publications, the main factor that seems to influence the mortality and morbidity rates associated with traumatic esophageal perforation is the time of diagnosis [5].

\section{Conclusions}

Esophageal rupture is a very rare clinical entity. As the condition can be life-threatening, it should be taken into consideration in every patient after blunt trauma of the neck and chest region with coexisting subcutaneous emphysema, especially in the absence of pneumothorax in CT examination.

\section{Disclosure}

Authors report no conflict of interest.

\section{References}

1. Andrade-Alegre R. Surgical treatment of traumatic esophageal perforations: analysis of 10 cases. Clinics (Sao Paulo) 2005; 60: 375-380.

2. Henderson E, Echavé V, Lalancette $M$, Langlois G. Esophageal perforation in closed neck trauma. Can J Surg 2007; 50: E5-E6.

3. Strauss DC, Tandon R, Mason RC. Distal thoracic oesophageal perforation secondary to blunt trauma: case report. World J Emerg Surg 2007; 2: 8.

4. Cedeńo A, Echeverría K, Vázquez J, Delgado A, Rodríguez-Ortiz P. Intrathoracic esophageal rupture distal to the carina after blunt chest trauma: case-report. Int J Surg Case Rep 2015; 16: 184-186.

5. Peitzman AB, Rhodes M, Schwab CW, Yealy Dm, Fabian TC. The trauma manual: trauma and acute care surgeon. Medipage, Warsaw 2010.

6. Oray NC, Sivrikaya S, Bayram B, Egeli T, Dicle O. Blunt trauma patient with esophageal perforation. West J Emerg Med 2014; 15: 659-662.

7. Delos Reyes AP, Clancy C, Lach J, Olorunto WA, Williams M. Conservative management of esophageal perforation after a fall. Int J Surg Case Rep 2013; 4: 550-553. 